Accepted for publication in Celebrity Studies published by Taylor and Francis. The version of record is available at: https://doi.org/10.1080/19392397.2018.1563337

\title{
The Analogue Strikes Back: Star Wars, Star Authenticity, and Cinematic Anachronism
}

David Fleming, University of Stirling, Scotland

Adam Knee, Lasalle College of the Arts, Singapore

It is a basic maxim of celebrity studies that for Hollywood cinema — as indeed for most rationalized film industries - star presence is a key means of product differentiation, and thus central to profitability. In many ways this remains as much if not more so under contemporary blockbuster economics: Blockbusters of course rely heavily on big budget special effects and narrative 'hooks', but producers generally also want their multi-million dollar investments protected with the presence of commensurately expensive big-name stars, which can help guarantee a baseline attendance level.

This essay will make the case that Star Wars: The Force Awakens (J.J. Abrams, 2015), one of the most highly publicized and widely anticipated of recent blockbuster films, embodies this reliance upon star presence in an exceptional and extreme way, to an extent that produces significant textual effects at a variety of levels. We here also expand the notion of the 'star' to account for the nonhuman, the non-biological, and the more-than-human, for reasons that will shortly become clear. More specifically, we shall argue, The Force Awakens is premised upon and preoccupied with the authentic and in a way authenticating presence of the main stars of the first wave of Star Wars productions (1977-83). ${ }^{\mathrm{i}}$ These historically/extra-diegetically (though not narratively) earliest films and their stars had already become bound up with a discourse of authenticity not only in their constituting the originary moment of the series, but, perhaps even more so, in contrast to the subsequent 1990s CGI-heavy Star Wars prequel trilogy ${ }^{\mathrm{ii}}$ — which disillusioned many loyal fans for (among other things) its displacement of 'real' special effects and authentically present characters (that is to say, the presence of actual models, suited actors, and so on) in favour of the virtual. This preoccupation with the authentic was moreover redoubled at the time of The Force Awakens owing to the sale of production company Lucasfilm to the Walt Disney Company in 2012 and original directorproducer George Lucas's concomitant loss of authorial control over the saga, what Gerry Canavan has rightly described as 'a moment of epistemic break for the Star Wars franchise' (Canavan 2017, p. 277).

Director J.J. Abrams was speaking directly to such concerns, and to these fans, when, in 2015, he proclaimed that his new sequel would hark back to more 'authentic' practical effects, and shortly afterwards also confirmed that the new film would not be shot digitally, but rather using already 
anachronistic celluloid film. In combination with a return to 'zombie media' forms of more authentic or indexical modes of image production, the new film also promised to see the return of the original writers and composer, as well as veteran cast members such as Carrie Fisher, Harrison Ford, Mark Hamill, Anthony Daniels and Peter Mayhew. Our contention here is that while the presence of these (real) actors threatens an ontological rupture, by asserting a radically disparate frame of reference to that of the plot in terms of reality and temporality, older legacy media forms have also now begun to surface as comparable (and also potentially disruptive) quasi-stars or 'actors' in their own right, and are increasingly recognised as key players in what finally constitutes an authentic ontological Star Wars experience.

We will be seeking to describe, then, how Star Wars: The Force Awakens functions through several simultaneously operating levels of meaning which cross-reference one another: The diegetic structure of the film's plot functions in continual interaction with a narrative of star presence and intertextual star discourse, as well as a further related narrative about technological developments within the medium - and, arguably, further still, a narrative about the industrial evolution of a blockbuster franchise and the issues of repetition and decline that arise with proliferating iterations. We approach this by way of, first, an account of the film's implicit hermeneutic of star revelation, and then an analysis of the associated layerings of extra-diegetic star discourses and technological discourses respectively. Given the difficulty of adumbrating such a complex system of dynamic interactionsamong the textual and the extra-textual, the human and the technological, and so on -we turn in the final portion of the essay to explore a theoretical model capable of encompassing the kind of cinematic phenomenon we wish to account for. More specifically, we conclude the essay by proposing the use of sociology's 'actor-network theory' as a model which can accommodate precisely the kinds of cross-realm movements and networking we postulate as occurring across numerous levels of The Force Awakens.

\section{Plotting a course through the stars}

One of the manifestations of The Force Awakens' impulse to hearken back to the initial beloved trilogy, and in particular to Star Wars: Episode IV - A New Hope (1977), is, in plot terms, a substantial number of replications of key narrative elements — celebrated or iconic moments—of those earlier texts, as various fans and critics did point out. The broader dramatic trajectory of the narrative once again concerns the developing relationships among a trio of young protagonists, again a woman and two men, who are brought together in their struggle against an 'evil empire' (now the First Order 
rather than the Galactic Empire) with ambiguous hints of romance again emerging along the way. These are, more specifically, Rey (Daisy Ridley), Finn (John Boyega), and Poe (Oscar Isaac), though the second male character, Poe, ends up notably deemphasized in this film as Rey herself takes on some of the 'masculine' functions from the earlier narrative- and like one of the heroes of the earlier texts, her own personal demons involve the trauma of the loss of her parent figures. The protagonists are again aided in their exploits by a comical robot, again narratively deployed to bring humour to the storytelling. And again, the protagonists' struggle against the larger totality of the Empire in part takes on the more personal conflict with a tall, masked, black-clad representative of that empire, one in possession of exceptional telekinetic powers but also undergoing his own internal struggle between the forces of light and darkness, good and evil; that figure being one Kylo Ren (Adam Driver), clearly stepping into the earlier narrative functions of Darth Vader (whom we learn is his grandfather). On a larger scale, the trio once again work to curtail the destruction wrought or threatened through the evil Empire's advanced weaponry, the deadly Starkiller Base now replacing the earlier Death Star. And in the (re)telling of this story, the filmmakers (by their own admission) also offer certain very clear revisitations of key iconic moments of the earlier films - for example, a visit to a frontier bar with colourful alien patrons and whimsical live alien musical performances, an exciting attack upon the main Empire base requiring the deft solo piloting skills of one of the protagonists, and a climactic father-son light-sabre fight which includes a fall down an air shaft.

For a fan or indeed any audience member already well-versed in the 1977-83 trilogy, this plotting might seem unimaginative, even dull. However, we would argue that a secondary, more covert narrative is also present, and that this is what gives the film its distinctive drive. To an unprecedented degree and in a distinctive fashion, all of The Force Awakens' cinematic codes are arrayed to support a certain secondary hermeneutic concerning authentic star presence. So that while on a surface level, the film might seem to be organized around such turning points as being discovered by the enemy, being rescued by allies, doing battle with the enemy, and so on, we would argue that the film is structured as much if not more so by the moments of the appearance of the 1977-83 trilogy's original stars - Ford, Fisher, and Hamill — in the flesh. To offer a more specific illustration, while classic narrative logic would take the film's first main turning point, the close of its first act, as being one of the points at which Finn feels motivated to joint Rey on her quest, in the film's secondary narrative of star presence, what is far more important a turning point is the entrance of Harrison Ford as Han Solo, to satisfy the audience's curiosity about how he will look in the role after the lapse in real-world time, and to satiate the fan's craving to see him take up the heroic mantle again. The coverage of the scene, moreover, makes consummately clear the filmmakers' understanding of this fact, of the narrative gravity of the moment when Harrison Ford/Han Solo, accompanied by Chewbacca, unexpectedly steps onto his erstwhile ship the Millennium Falcon once more. The narrative focus on Rey and 
Finn's struggles and fears as they try to flee, and the focalization through them, is instantaneously dropped in favour of catering to the viewer's need to gaze upon Ford playing Solo, as we cut away from the young leads to a privileged close up of the newly arrived actor proclaiming to his alien comrade, 'Chewy, we're home.' While the film does of narrative necessity return to a focus on the younger protagonists soon enough, a principal of negotiating between Rey and Finn's causal chain of action and the fascination with Ford's star presence remains in play throughout the rest of the film.

As it is with Ford, so it is at least in kind (but by no means in degree) with his legacy co-stars Fisher and Hamill. When Fisher as the Resistance commander Leia comes with her troops to the aid of the protagonists as they fight off stormtroopers, and then steps from her ship, the extended moments of interaction between her and Ford are once more covered in formally privileged close-ups and given clear emphasis beyond what might be called for to forward the progress of the narrative, and their dialogue is full of lines that can clearly be taken to refer as much to their 'real' selves as actors as to their fictional characters, as when Han now explains to Leia regarding his life since they last had met, 'I went back to the only thing I was ever any good at'. Still further evidence of the purchase of this secondary 'narrative' of star revelation can be found in the subsidiary narrative goal of not only staving off First Order attack, but of piecing together maps that will reveal the location of Luke Skywalker (and thus of the third legacy star Mark Hamill). That this subsidiary goal has not yet been achieved even with the Resistance victory against the First Order (the surface narrative resolution) provides a pretext for the film to continue on until the hermeneutic imperative to find and witness the third star is able to play out. This occurs as Rey heads out to track him down in a narrative coda, wherein she finds him standing on a cliff on a remote island and in a literal moment of star revelation, Luke pulls his hood back to show the star's face to the expectant audience. With this important benchmark achieved, the film is able to abruptly move to its closing credits.

Certainly the closing moment raises numerous new narrative questions - such as about what Luke has been doing in the intervening years, what he will do now, and whether he will take the light sabre that Rey is holding out to him. Such continuing questions plainly provide the impetus for the narrative of the subsequent Star Wars: The Last Jedi (R. Johnson 2017). But the most fundamental questions of whether Hamill will be involved with the Last Jedi narrative, and what he will look like on screen, have at the least already been answered in the 2015 text - although yet another draw for viewers of The Last Jedi is curiosity about how Hamill's more extended performance appears. And in this fashion both the close of The Force Awakens and the start of The Last Jedi end up turning not so much on dramatic conflict and resolution, as on the presentation for inspection of the desired star body, the fulfilment of a cinematic writ of habeas corpus. 
Aside from bearing upon narrative structure and dramatic emphasis, the preoccupation with the presence of the authentic legacy star also registers in the film's temporality. Precisely where one ought to situate the Star Wars films in generic terms is open to debate, but at the very least one could see the films as engaging many of the conventions of science fiction - a genre typically associated with a sense of futurity and often as well characterized by tremendous flexibility in terms of time frames, both with respect to narrative leaps of time (think of the classic example of 2001: A Space Odyssey (1968)) and to diegetic science fictive technologies which allow the manipulation of time (all of which cinematic technologies are themselves well-suited to represent). However, in its investment in the authentic star presences of its legacy performers, The Force Awakens must set aside the usual futurity and temporal fluidity of the genre, yoked as it is to the real-world temporalities of these star bodies, as well as to the short-term time frames of the fictional characters they represent (who need be retained in the sequel so that the stars too can plausibly be retained).

Indeed, even the usually forward-moving sense of a sequel is diminished here in that, as noted earlier, the The Force Awakens narrative replicates numerous elements of the 1977-83 trilogy, A New Hope in particular. To put this another way, the text's compulsion to salvage a celebrity past, its desperate nostalgia for an earlier textual epoch and its authentic stars, renders it as much a remake as a sequel. The need to offer innovation and product differentiation and relevance for new audiences thus arguably becomes secondary to preserving this (star) vehicle's precious celebrity cargo. This of course is not to argue that innovation is completely eschewed, and, indeed, in current parlance The Force Awakens might be more precisely described as a 'reboot' than a remake in particular in the sense that it establishes new (putative) lead protagonists while having the earlier protagonists (and actors) operating alongside them. More specifically, The Force Awakens knowingly nods to the shifting social politics of its new historical context of production, in the 2010s, by making one of its new key protagonists a black male and the other a very strong and independent female (Finn and Rey respectively). It is telling, however, given the preoccupation with Ford in particular (as the legacy star with the most currency as a celebrity), that the film seems unable to make his presumed narrative replacement Boyega appear admirable and heroic. While Finn from time to time is able to demonstrate some skills as a team member (having the weaponry background of a former First Order stormtrooper), and while from time to time he offers selfless or brave gestures or clever initiatives, for the most part he seems strikingly ordinary in comparison with his exceptional partners, and repeatedly shows traits of both cowardice and pompous bluster. The upshot is that it is surprisingly difficult to know how to 'read' Finn - whether we are supposed to see him as an empathetic everyman in his ordinariness, or as a hero-in-development to be admired for his (not very clear) character growth, or 
as comic relief, there is a striking lack of coherence in his characterization. We would argue that this failure to achieve a convincing and unified portrayal of the character who would be Han Solo's narrative replacement can be taken as a joint symptom of both Harrison Ford's subterranean dominance of the text and a legacy industry production machinery's continuing ill-preparedness for negotiating contemporary racial politics. ${ }^{\text {iii }}$ (The character name itself, Finn, in fact reverberates with the protagonist's name in another classic American text known for the problems it poses for reading race, generating interpretive debate to this day: Mark Twain's 1884 Adventures of Huckleberry Finn.)

To approach the narrative's relation to contemporary (2015) politics from another angle, if John Boyega as Finn is this film's Barack Obama - an African-American leader who has arisen from a dominant power bloc (the First Order/the Democratic Party) to support progressive causes and marginalized groups in his new role, but who sometimes appears less than decisive, forceful, and effective in achieving these goals - then Harrison Ford as Solo is its Bill Clinton-a sometimes reckless, womanizing leader of an earlier generation who, despite his personality foibles, is widely admired for his charisma and leadership, and who supports his younger African-American protégé from a distance. ${ }^{\text {iv }}$ Ford is plainly the one who provides the real narrative impetus here, and while Solo's apparent passing toward the end of the film would seem, in classical narrative mode, to mark a transition from old patriarchy to new (in the form of Boyega/Finn), ${ }^{\mathrm{v}}$ it ultimately transpires that this ends up not the overarching narrative's most primary focus. The narrative interest, rather, gets handed off to Daisy Ridley's Rey, who takes on the function of not one but two main characters of the earlier films: she is the successor of Luke Skywalker as an heroic figure separated from her parents and linked to the Force, but also the substitute for Leia as the female protagonist and object of male protagonists' desires. And, relevant to the larger argument being made here, her own larger quest of determining the whereabouts of and traveling to encounter Luke Skywalker aligns exactly with the deeper hermeneutic code of the film, the drive to witness the legacy performers.

\section{Star discourses}

This preoccupation with the legacy stars' authentic, real-world biological existences (and a nostalgia for their earlier incarnations) not surprisingly registers in the extra-textual circulation of discourses regarding the stars (and their appearances in the film) as well in the time period during the production and distribution of The Force Awakens. In the case of Harrison Ford, the star with by far the greatest continued industry success, including substantial amounts of work above and beyond the Star Wars franchise, this strikingly takes the form of a narrative of physical vitality and resilience which 
reassuringly validates an apprehension of an identity between Ford and Solo. This narrative arose most centrally in media coverage of Ford's crashing his own plane in the period just after the shooting of the film (see, for example, White et al 2015). Aside from the fact of Ford/Solo flying his own craft in real life as on screen - a fact humorously alluded to in circulating memes with the Millennium Falcon photo-shopped into the actual crash scene-there was a heightened scrutiny of Ford's ability to walk away from the crash relatively unscathed and of the progress of his physical recovery, communicated to the public through stolen paparazzi glances of Ford being helped with a wheel chair and then crutches. This narrative of physical resilience while in activities that merge Ford and Solo was also evident in reporting of Ford/Solo becoming seriously injured on the (filmmaking) job, as the door of the Falcon (or, depending upon vantage point, the set representing the Falcon) closed on Ford/Solo's leg, resulting in real-world legal action from UK workplace safety authorities. But the seriousness of the injury (a broken leg) notwithstanding, Ford was indeed able to return to work before long and appeared none the worse for wear at the press junkets on the eve of the film's premiere.

In the case of Ford's less successful legacy actor colleagues Hamill and Fisher, however, there arise the twinned issues of less continuity in their post 1983 star biographies and, as a result, a less seamless match between their extra-textual 'realities' and their character images, rendering more problematic the nostalgic impulse to experience the stars much as they once were. On the one hand, this did offer a potentially profitable textual 'hook', with (as mentioned above) audiences curious to witness the form of the stars' re-emergence in the series, the present state of their bodily appearances and performances, while on the other, it posed the threat of audience disappointment (and possible negative reaction) in the eventuality of images not meeting desires and expectations. Hamill, for example, was known by fans to have fallen on hard times both in career terms and in terms of bodily fitness, transitioning from boyish, slender hero to bloated, raspy-voiced villain. In fairness, Hamill did in some sense continue to have a successful working career as a performer, being much in demand as a voice actor for animated television series (and, later on, video games), often in villainous roles (notably the Joker in various Batman games), from the early 1990s right up until the time of The Force Awakens. But the fresh-faced Hollywood hero who was Hamill in the initial Star Wars trilogy releases ended up in the late 1980s to early 1990s in a string of low-budget and poorly received genre films and made-for-TV movies, after which he largely disappeared from movie and television screens (though not from their recorded voice tracks). Among the very few on-screen roles Hamill played in the years immediately prior to The Force Awakens were those of a serial killer in two 2013 episodes of Criminal Minds and a long-haired violent psychopath in the little-distributed thriller Sushi Girl (2012). A number of the circulating images of Hamill in these years from his few photographed film roles and from public events showed him, moreover, to be noticeably chubby, seemingly not 
physically fit (some of these collected, for example, in Nixon 2015). The concern or curiosity over the shift in bodily form can be seen registered in the numerous media references to how trimmed down and fit the actor appeared when he was seen at press and publicity events for the release of The Force Awakens, and the impression of a Hamill who had returned to physical fitness is briefly confirmed in the closing shots of the film. It could be argued at the same time that Luke's intense and as-yet unexplained facial expression in those shots plays simultaneously to the sense of Mark Hamill's increasingly crazed or villainous star persona and suggestions of Luke Skywalker's own struggles with the Dark Side. And it is again commercially productive, as a 'hook' for the follow-up Star Wars: The Last Jedi (2017), that The Force Awakens closes with Luke's expression kept ambiguous for the time being.

Like Hamill's career, Carrie Fisher's career did not remain at (or grow from) the top level of stardom seemingly promised by her success in the initial Star Wars trilogy; Fisher continued to work with modest regularity between The Empire Strikes Back and Return of the Jedi, but in featured rather than starring roles in films and television shows of varying budgets and profiles. Her star discourse was overshadowed, moreover, by various reports of substance abuse problems, and her unabashed, selfdeprecating attitude about both her drug use and her active sex life - though it must be said that Fisher's famous outspokenness in some senses coheres relatively well with Leia's own oftdemonstrated feistiness. In any event, Fisher's relative lack of concern about being linked to the scandalous made her with some frequency a ready target for both lurid tabloid news reports and television comedians' barbs. As with Hamill, then, there was audience curiosity and concern about whether the actress could return to form, whether the former Leia would be seen again in a comparable image to her earlier one-and studio awareness of this was registered in its pressuring of Fisher to lose weight for her return to role (her complaints about this having been widely quoted; see Child 2015).

As it happens, in neither her press junket nor premiere gala appearances, nor the film itself, does Fisher look strikingly heavier than her younger self, or noticeably out of shape for her age—indeed, by appearances, she would seem to have a comparable physical profile to that of her fellow legacy stars - one of them (Hamill) a man five years her senior, the other a full 14 years older. Nevertheless, and unlike her male legacy co-stars, Fisher was subject to a great deal of social media "bodyshaming" for perceived shortcomings in her appearance. On the one hand, this unequal response quite directly highlights the gender imbalance of both Hollywood's expectations and the audience's, as Fisher immediately and forcefully pointed out with her typical acerbic wit (Child 2015). But at the same time, and in keeping with our argument here, the emphatic and arguably irrational nature of the 
fan reaction to her indexes the kind of desperate nostalgia we alluded to earlier, the need to see the beloved star's physical presence as it once was. As a female star who was in one of the earlier films required by the producers to display a then-lithe body in an image that has become iconic (Princess Leia in a gold bikini), her current appearance is that much further from fan preconceptions, the authentic body (whether reasonably fit or not) that much more difficult for some of them to come to terms with. Both sexist double-standards and fan nostalgia then collude to foster a disproportionately negative response to Fisher. Nor does it help matters that the present production team appears incapable of imagining a 60 year old woman as having a sexual identity: Even though there had famously been a strong erotic frisson between Leia and Solo in the earlier films (and, as it now turns out, between Fisher and Ford in real life as well), even though they have had a son together, the embrace between the two in The Force Awakens bizarrely appears more like that between a father and daughter than between two passionate ex-lovers, with Solo holding Leia's face to his (of course fully clothed) chest.

\section{Non-human legacy actors as stars}

The Force Awakens's preoccupation with the past and the authentic extends far beyond the narrative and star discourses outlined above, broadening to incorporate a nostalgic predilection for older technologies of representation. Of resonance here are more dispersed sentimental trends that Jussi Parikka links to our living in a time when the death of old media are mourned, and older 'vintage' forms are increasingly 'considered better than the new' (2012, p. 3). We might consider the fetishistic revival of vinyl records in this light, seeing how the crackling sounds, smells, and tactility of this plastic medium is increasingly cherished and prozelitysed by connoisseurs. Historically speaking, studies of celebrity have regularly paid heed to the impact of different media-such as the introduction of synchronised sound at the close of the silent era, celebrity magazines, or Twitter-in the making, breaking, and co-determining of a star image or system. However, what interests us on this outing is the extent to which anachronistic technologies and industrial standards appeared to become celebrated as quasi star 'actors' and legacy 'performers' in their own right, taking their place alongside the older biological cast.

Similar ideas can no doubt be gleaned from the positive crowd reactions recorded during the 2015 Comic Con Star Wars panel, wherein Abrams first confirmed to the (admittedly enthusiastic) crowd that his Star Wars film - in contradistinction to the CGI-heavy aesthetic of the prequel trilogy (19992005)—would mark a deliberate return to analogue filmmaking techniques, preferring 'practical 
special effects' in keeping with the look of the original 1977-83 trilogy. The staged announcement can no doubt be understood as cashing in on the anti-CGI sentiments of the more uncompromising Star Wars fans (and which found ireful expression in fan songs such as 'George Lucas Raped Our Childhood' (2005) and the documentary The People vs. George Lucas (2010)) and was engineered in this context to elicit an affirmative group response. Nevertheless, the Comic Con fans were in essence caught celebrating the return of what we can here call non-human legacy actors (or actor-networks more precisely, and more on which below) that contribute their own share to the authentic 'look' and 'feel' of the nostalgia laden franchise.

Undoubtedly, some might detect a slight irony in rejoicing in the old and familiar within a genre form that is typically associated with pushing the boundaries of technologies both in and beyond the frame. But we must not forget that the original 1977 Star Wars film always-already embodied contradictory telescoping temporal movements, with its own Janus faces looking both backwards and forwards. The New Hope was famously set in the far past of archetypal myth, for example, with its now famous opening title informing viewers that the galatic struggle occured 'a long time ago in a galaxy far, far away....' This ancient and grimy past was also a futuristic science-fiction universe, though, chock full of advanced robots, space ships, ion drive engines, and hologramatic imaging computers (albeit often on the verge of obsolescence or break down). And although the original became reknowned for its frontier-pushing special effects, J.D. Connor observes that certain stylistic choices—such as using 'retro wipes' and a pastiched 'space opera' style - were 'retrospectively' channelling the spirit of 1930s cinema (2016). In these push-pull gestures we can begin to apprehend a system of 'futural posteriority' or else 'posterior futurity' that can be fruitfully harnessed to help guide our understanding of Abrams's new but old, authentic yet novel, updated yet backdated Star Wars reboot.

Forty years on, Connor is correct to observe that 'the appeal of the 1930s is negligible' in Abrams's film, which now 'only weakly gestures toward the first film's wipes' (Connor 2016). Instead, he notes, The Force Awakens looks to occupy 'the 1970s themselves,' in a way comparable to how Indiana Jones and the Kingdom of the Crystal Skulls (another Ford vehicle) occupies the 1950s (Connor 2016). By such coin, The Force Awakens can be recognied as playing straight what Jack Plotnick's Space Station 76 (2014) performs for laughs_-by parodically entering into a retro 1970s past-future that oozes nostalgia for vintage technologies and analogue aesthetics (which 1970s futurologists presumably believed might inhabit and colonise tomorrow's world). Might we not say, then, that both Plotnick's Space Station 76 and Abrams's plot-nicked Force Awakens 77 each reveal through their form and content a common 'steam punk' philosophy, which is complementary to the 
spirit and ethos of the practice increasingly branded Media Archaeology? The methods of which, as Jussi Parikka renders it, attempt to 'think the new and old in parallel lines' (2012, p. 2). ${ }^{\text {vi }}$

As it happens, The Force Awakens self-consciously frames itself as a steam punk movie, even evoking such ideas through narrative acts of mise-en-abyme. For example, and as if reflecting on its own repurposing of key plot points and stars from the original movie as outlined above, the new main character Rey is a steam-punk scavenger and salvager, grafting her trade in a starship graveyard, wherein she repurposes bits and pieces of old wasted Imperial junk, in order to fashion new vehicles. Beyond story and symbolism, though, we can also creatively expand this notion to account for the film's own utilisation of old scavenged and repurposed media and industrial technê. Indeed, when asked about his filmmaking preferences in an interview Abrams tellingly noted that the way Lucas did things back on the first film essentially became his gold standard: 'The thing that struck me, that wouldn't get out of my head', he says 'is just how real you knew and felt Star Wars was when you first saw A New Hope. You couldn't deny it' (Abrams in Otero 2015). One of the most recognizable ways in which Abrams embodies a steam punk ethos, then, is through his preference for using what media archaeologists often refer to as 'zombie media' (see e.g. Parikka 2012: 147; Hertz and Parikka 2012). That is, obsolete, residual, or living-dead forms that remain with us, and functional, in their post-production afterlife.

In point of fact, Abrams sought 'legitimate and authentic' old-school technologies to help him replicate Lucas's now historical benchmark - which was of course cutting edge and boundary shifting in its original context (doubled down future posteriority here?). Sticking to brand message, production designer Darren Gilford also (dutifully) reported in a paratextual interview that:

J.J.'s mandate from day one was authenticity and being as true to the original trilogy as possible. And he felt the prequels were flawed by the fact that they had every [CGI] tool known to mankind and used everything at their disposal. I use the metaphor of disco when the synthesizer came about and everyone was using it in any way possible. And I think J.J. wanted to reconnect with how the original films were made (McKnight 2015).

Furnishing his claims with examples, Gilford notes how Abrams 'used flat forced perspective paintings to do things like make a hallway or corridor appear longer than they actually are, and basically went practical and physical whenever they could' (McKnight 2015). In a slew of other ephemeral press releases, an even more expanded list of old media formats and filmmaking techniques likewise became fetishistically listed and accredited, in a reversal of the usual science 
fiction blockbuster trend of marketing the film as employing the latest cutting edge forms of CGI spectacle. To this selective list we might also add Panavision cameras, Kodak film stock, animatronic aliens, and a classical orchestral score, composed by the original scorer John Williams, and performed by the Freelance Orchestra on authentic (as opposed to synthetic or digital) instruments.

Such notions suggest that Bruno Latour's actor-network theory (ANT) becomes a useful conceptual framework for comprehending how Star Wars' filmmaking technologies might be recognised and accredited as agential actors in their own right. For ANT famously rejects privileging or centralising the role of human actors within productive networks, demanding instead we recognise the key role that non-human, inhuman and unhuman actors and actants play within larger and more distributed assemblages. Pulling such a refocus also ostensibly demands that we liberally expand the notion of what an 'actor' actually is, to account for anything whatsoever that is, in the last analysis, 'granted to be the source of action' (Latour, p. 373). Star Wars offers itself as a particularly pertinent franchise with which to think through such ideas. For, on one level, the saga's fictional universe sees human and nonhuman actors alike placed on equal footing. For example, we might anecdotally recognise how a Star Wars viewer could be a fan of the irrepressible R2D2 droid just as much as, if not more than, his sulky humanoid companion: teenage Luke. Simultaneously, beyond the fictional diegesis, the production of the episodic series also spans forty years of ever-changing 'actorly' technological developments, with the middle trilogy serving to traverse the so-called digital divide (putting to one side on this outing how the films' tie-in artefacts—-such as toys, games, and merchandise — also began radically expanding the ways in which fans imagined and interacted with the expanded tranmedia universe (see for example Jenkins and Hassler-Forest 2017, p.17)).

In tracking back from the anecdotal to the academic, we can begin overlaying Latour's ANT models onto the production of The Force Awakens by re-recognising 'actors' as anything at all 'that acts or to which activity is granted by others' (1996, p. 373). Thinking through these points inside and outside the films immediately serves to open up intriguing vectors that pierce through the wider cultural assemblage to which they belong and from which they emerge. To chart a slightly circuitous route into these issues, we might recall how the Wookie Chewbacca (Peter Mayhew) was famously inspired by and based upon a pet dog that often sat perched in the passenger seat of Lucas's car (see Andonovska 2017). Zigzagging into the fiction, we might in turn recollect how at the end of A New Hope, somewhat scandalously, Chewbacca is not awarded a medal-like all his human counterparts-for his valiant efforts in blowing up the first Death Star. ${ }^{\text {vii }}$ Back in the real world, we can rest assured that nowadays the best cinematic dog actors do regularly get rewarded and awarded at prestigious award ceremonies. We think here specifically of the Cannes Film Festival's non-human 
Palm Dog Award, which was initiated in 2001 and has been annually recognising doggish actors ever since. Beyond biological nonhuman actors such as canines (and Wookies), it is worth mentioning that within and without the Star Wars universe machines are likewise important actors that display their own unique qualities, personalities and quirks. And these too often receive accolades and awards for their actions and effects, albeit at segregated ceremonies (such as the Academy Award for Technical Achievement). In this outing we would invite viewers to recognise the fictional analogue droids as allegorical surrogates or stand-ins for a wide range of other behind the scenes analogue technologies - viz, the now retro machines that were originally used to fabricate and index the Star Wars universe. ${ }^{\text {viii }}$

Our main contention here is that it is in part precisely these invisible (yet discernable) forms of inhuman machinic actors that the Star Wars fans cheered and welcomed back at Comic Con, in recognition of their networked behind-the-scenes contributions to the authentic texture and feel of the legacy universe. In the well-received Comic Con press release teaser trailer, for example, we can locate a prominent sequence that fetishistically frames a Panavision camera standing on its tripod in a desert setting. The recording machine's outer casing is there opened up by its human operator so that its motorised innards and reels can be seen mechanically spinning and whirring-echoes here of the famous scenes from A New Hope where R2D2 and C3P0 move through a similar desert milieu before becoming salvage junk for the steam punk Jawas. As if confirming this, this techy shot of the apparatus' black box being opened up is edited together with an image of C3P0's golden casing being fastened shut, presumably atop the absented silvered actor Anthony Daniels (the proverbial human ghost in the shell). As indicated, beyond the motorised legacy cameras, it was also extensively reported in the press that material Kodak film stock was also being used to capture Abrams's new Star Wars images - this constituting yet another entangled vintage actor that was celebrated in the film's paratexts because its silver halide granules actually (or authentically) became inscribed by the touch of the real qua light (as opposed to being composed of 'pixel paint' from the digital dark side). Of course, before The Force Awakens was even slated, Kodak film had grown famous as the preferred medium of a certain generation of celebrity cinephile directors, such as Quentin Tarantino, Christopher Nolan, and Abrams (see Cade 2014) — a powerful auteur mob who individually and collectively helped analogue film stock re-emerge as an anachronistic connoisseurial standard in the digital era. Thus, as was the case with vinyl records, vintage film suddenly gained a renewed appreciation and prestige in its post-digital afterlife as a living-but-dead zombie media form(at). In trying to explain the lingering popularity of this otherwise obsolete format, Kodak's commercial film president Andrew Evenski tellingly explains that: 'We've had a lot of success with people coming back to film, mainly because (of) the aesthetics of it, [...] It's more natural looking' (Zhang 2015). In making a brief parenthetic return to our argument that the droids themselves can be read as stand-ins 
for such analogue media forms, we might recall that the name R2D2 was itself famously based on the acronymic abbreviation of 'Reel Two Dialogue Two', which Lucas had recalled from his experiences of editing together his prior nostalgia laden film, American Graffiti (1973).

Collectively, it is these forms of distributed actor networks that we argue grants The Force Awakens what Brent McKnight refers to as its 'very concrete, tactile feel' (2015). We might add that the music is another important actor or force here in the character of Wagnerian operas. Certainly, various paratextual discussions of the film's affective musical arrangements bring to mind Ian Buchanan's discussion of why the term arrangement offers itself as far better translation for Deleuze and Guattari's French concept agencement, than does Brian Massumi's translation 'assemblage' (see Buchanan 2015). For, assemblages or (working) arrangements, like Latour's ANT, display agency, and are best understood as dynamic distributed networks that come together and 'do things', while demanding we think of them 'in terms of nodes that have as many dimensions as they have connections' (Latour 1996, p. 370). Arguably, the feelings of Star Wars authenticity achieved by The Force Awakens is best conceived as the result of exactly such a parliament of legacy (human and nonhuman) actors joining together into an agential network of nodes. A quick mind experiment should help to drive home this idea, for we would maintain that the authentic biological bodies of Ford, Fisher and Hamill would most likely look odd or 'off' if they were recorded with more modern digital cameras that create a crisp 50 to $150 \mathrm{HD}$ frames per second. Or at least, they would appear ontologically and optically/ontically different to the way they did in the original 1977-83 trilogy. Which is to say, it is only with the authentic legacy Panasonic and Kodak actors recording them in 'real' sets that they can resume their 'authentic' star (wars) status. ${ }^{i x}$ Accordingly, we might concede that the nonhuman image-making machines and technological actors do appear on-screen with and alongside the legacy humans they image, and can therefore be conceptualised as weaving perceptible emperor's 'retro' clothes around them - that is, palpably yet transparently enrobing and folding their silver flecked biological bodies and carbon costumes within their own emulsified silver grains. In the last analysis, it is exactly this expanded network of performing bodies that the fans celebrated at Comic Con, which in turn allows us to square the special effect of these authentic and anachronistic actor assemblages with what the corresponding diegetic characters speak of when they tell us that there is a profound force that surrounds us, and penetrates us, and binds our galaxy together.

By way of a concluding observation, we would acknowledge that the next film in the series, 2017's The Last Jedi, does not place near the same emphasis on discourses of authenticity, nor on such studied fidelity to earlier Star Wars traditions - witness the 2017 film's much lesser dependence on legacy protagonists/performers and its introduction of numerous new characters, not to mention 
multiple new CGI-based creatures. The fact that The Last Jedi was a box office (and critical) success even with these numerous shifts might indeed at first appear to undermine our claims about the pleasures of The Force Awakens. We could also point, however, to the fact that the 2017 film caused considerable division within the fan community described above, and elicited a notably more positive press reception than audience reception, reportedly owing in large measure to the new film's perceived lack of adherence to traditions, its numerous novel plot lines, its unaccustomed predominance of humor, and so on (see Youngs 2017, for example). Moreover, the clear narrative emphasis given to Hamill-as-Luke, and the emotional weight of the scene where he once more encounters Fisher-as-Leia, speak to an understanding of the persistence of the force of authentically present legacy actors. Finally, the power of this force can be read once again in the producers' decision to alter the franchise's planned plot trajectory upon the death (in December 2016) of star Fisher, removing Leia from a later main-series narrative rather than finding an alternate performer for the role or using a CGI version of the character (Kamp 2017), ${ }^{\mathrm{x}}$ in recognition of the indispensability of star presence.

\section{References}

2001: A Space Odyssey, 1968. Film. Directed by Stanley Kubrick. UK/USA: MGM.

American Graffiti, 1973. Film. Directed by George Lucas. USA: Universal Pictures.

Andonovska, A., 2017. The character of Chewbacca was inspired by George Lucas' tall hairy Alaskan Malamute. The Vintage News. Available from: https://www.thevintagenews.com/2017/11/02/thecharacter-of-chewbacca-was-inspired-by-george-lucas-tall-hairy-alaskan-malamute/.

Buchanan, I., 2015. Assemblage Theory and its Discontents. Deleuze Studies, 9 (3), 382-392.

Cade, D.L., 2014. Big Name Filmmakers Come to Kodak's Rescue, Push Deal to Save Motion Picture Film. PetaPixel (July 31). Available from: http://petapixel.com/2014/07/31/big-name-filmmakerscome-kodaks-rescue-working-deal-save-motion-picture-film/.

Canavan, G., 2017. Fandom Edits: Rogue One and the New Star Wars. In Guynes, S. \& HasslerForest, D., (Eds) Star Wars and the History of Transmedia Storytelling. Amsterdam University Press, pp. 277-288.

Child, B., 2015. Carrie Fisher blasts Star Wars body shamers on Twitter. The Guardian (Dec 30). Available from: https://www.theguardian.com/film/2015/dec/30/carrie-fisher-blasts-star-wars-bodyshamers-twitter-social-media.

Connor, J.D., 2016. Making Things Right: Star Wars Episode VII: The Force Awakens. Los Angeles Review of Books (January 7). Available from: https://lareviewofbooks.org/essay/making-things-rightstar-wars-episode-vii-the-force-awakens/.

Criminal Minds, 2013. Season 8, Episode 23, The Brothers Hotchner. TV, CBS. May 22.

Criminal Minds, 2013. Season 8, Episode 24, The Replicator. TV, CBS. May 22. 
George Lucas Raped Our Childhood, 2005. Song. Recorded by Hot Waffles. Ready To Laugh. USA.

Handy, B., with photographs by A. Leibovitz, 2015. The Daring Genesis of J.J. Abrams's Star Wars: The Force Awakens. Vanity Fair (June). Available from:

https://www.vanityfair.com/hollywood/2015/05/star-wars-the-force-awakens-vanity-fair-cover.

Hertz, G and Parikka, J,. 2012. Zombie Media: Circuit Bending Media Archaeology into an Art Method. Leonardo, 45 (5), 424-430.

Indiana Jones and the Kingdom of the Crystal Skull, 2008. Film. Directed by Stephen Spielberg. USA: Paramount Pictures.

Jenkins, H. and Hassler-Forest, D., 2017. 'I Have a Bad Feeling About This': A Conversation about Star Wars and the History of Transmedia. In Guynes, S. \& Hassler-Forest, D., (Eds) Star Wars and the History of Transmedia Storytelling. Amsterdam University Press, pp. 15-31.

Kamp, D., with photographs by A. Leibovitz, 2017. Cover Story: Star Wars: The Last Jedi: the Definitive Preview. Vanity Fair (May). Available from:

https://www.vanityfair.com/hollywood/2017/05/star-wars-the-last-jedi-cover-portfolio.

Latour, B., 1996. On actor network theory: A few clarifications plus more than a few complications. Soziale Welt, 47, 369-381. Reproduced online at: http://www.bruno-latour.fr/sites/default/files/P67\%20ACTOR-NETWORK.pdf.

Libbey, D., 2016. Why Chewbacca Didn't Get A Medal At The End of Star Wars: A New Hope. CinemaBlend. Available From: https://www.cinemablend.com/new/Why-Chewbacca-Didn-t-GetMedal-End-Star-Wars-Hope-91807.html.

McKnight, B., 2015. The Extreme Lengths JJ Abrams Went To Connect The Force Awakens To The Original Star Wars Trilogy. CinemaBlend. Available from:

http://www.cinemablend.com/new/Extreme-Lengths-JJ-Abrams-Went-Connect-Force-AwakensOriginal-Star-Wars-Trilogy-72581.html.

Nixon, T., 2015. The Empire Strikes Fat: Take a Luke at Mark Hamill's Amazing Weight Loss. The Sun (Dec 15). Available from: https://www.thesun.co.uk/archives/news/871583/the-empire-strikesfat-take-a-luke-at-mark-hamills-amazing-weight-loss/.

Otero, J., 2015. Star Wars Celebration: Why Star Wars 7 uses Practical Effects. IGN (April 17). Available from: http://in.ign.com/star-wars-episode-vii/75014/news/star-wars-celebration-why-starwars-7-uses-practical-effects.

Parikka, J., 2012. What Is Media Archaeology?. Cambridge: Polity.

Rogue One: A Star Wars Story, 2016. Directed by Gareth Edwards. USA: Lucasfilm.

Shepherd, J., 2016. Star Wars The Force Awakens: JJ Abrams responds to criticism about the film being A New Hope 'rip off'. The Independent (Jan 10). Available from:

http://www.independent.co.uk/arts-entertainment/films/news/jj-abrams-criticism-star-wars-the-forceawakens-a-new-hope-rip-off-a6804546.html.

Space Station 76, 2014. Film. Directed by Jack Plotnick. USA: Rival Pictures.

Star Wars: Episode IV-A New Hope, 1977. Film. Directed by George Lucas. USA: Lucasfilm.

Star Wars: Episode V-The Empire Strikes Back, 1980. Film. Directed by Irvin Kershner. USA: Lucasfilm. 
Star Wars: Episode VI-Return of the Jedi, 1983. Film. Directed by Richard Marquand. USA: Lucasfilm.

Star Wars: Episode I - The Phantom Menace, 1999. Film. Directed by George Lucas. USA: Lucasfilm.

Star Wars: Episode II - Attack of the Clones, 2002. Film. Directed by George Lucas. USA: Lucasfilm.

Star Wars: Episode III - Revenge of the Sith, 2005. Directed by George Lucas. USA: Lucasfilm.

Star Wars: The Force Awakens, 2015. Film. Directed by J.J. Abrams. USA: Lucasfilm.

Star Wars: The Last Jedi, 2017. Film. Directed by Rian Johnson. USA: Lucasfilm.

Sushi Girl, 2012. Film. Directed by Kern Saxton. USA: Assembly Line.

The People vs. George Lucas, 2010. Film. Directed by Alexandre O. Phillippe. USA \& UK: Exhibit A Pictures.

White, C., Collman, A., and Rahman, K., 2015. 'Everything he did was perfect': Cool reactions of skilled pilot Harrison Ford, 72, credited with saving his life after he crash landed vintage plane on a golf course when its engine failed. Mail Online (Mar 6). Available from:

http://www.dailymail.co.uk/tvshowbiz/article-2981920/Harrison-Ford-rushed-hospital-criticalcondition-crashing-vintage-plane-golf-course.html.

Youngs, I., 2017. Star Wars: The Last Jedi - the most divisive film ever? BBC News [Online] (Dec). Available from: http://www.bbc.com/news/entertainment-arts-42424445.

Zhang, M., 2015. 'Star Wars: The Force Awakens Was Shot on Film, and Kodak May Be Profitable in 2016' PetaPixel (Dec 16). Available from: https://petapixel.com/2015/12/16/star-wars-the-forceawakens-was-shot-on-film-and-kodak-may-be-profitable-in-2016/.

\section{Endnotes}

\footnotetext{
${ }^{\mathrm{i}}$ More specifically, Star Wars: Episode IV - A New Hope (1977), Star Wars: Episode V-The Empire Strikes Back (1980), and Star Wars: Episode VI-Return of the Jedi (1983).

${ }^{i i}$ Comprising Star Wars: Episode I - The Phantom Menace (1999), Star Wars: Episode II - Attack of the Clones (2002), and Star Wars: Episode III - Revenge of the Sith (2005).

iii It is relevant to mention here that a controversy erupted during the release of The Force Awakens over the marked deemphasizing of John Boyega's image in the China-market advertising for the film, a move decried as racist. Whatever the local cultural reasons for Boyega's demotion, however, we would note (along the lines of the analysis being made here) that the film text in and of itself already positions Finn as less substantial in numerous ways than the film's other main characters, a fact again seemingly symptomatic of the film's own a priori racial problematics.

iv Admittedly, Obama's image was burnished considerably from mid-2016, both in nostalgic retrospect of his closing 8 year term of service and in positive contrast to the widely reviled candidates to replace him, as suggested by his rising approval ratings. However, at the time of the release of The Force Awakens late in 2015, the negative kind of perception described here still had a stronger currency.
} 
${ }^{\mathrm{v}}$ This transition from Solo to Finn — as a patriarchal hand-off — could also simultaneously be read as paralleling the shift between author-fathers Lucas and Abrams.

${ }^{v i}$ These parallel lines are often conceptualised in geological terms, as formulating sedimented layers that form one atop another. As with real-world geology and topologies, recent ruptures and shifts can result in hidden layers becoming re-exposed, revealing otherwise hidden folds 'of time and materiality,' which become opened up for renewed attention and discoveries (Parikka 2012, p. 3).

vii There are competing canon and conspiracy theories within fan communitites as to why Chewbacca did or did not receive a medal. Beyond discussions of Wookie traditions and Rebel racism, several real world explanations seem most convincing. The most likely of these being that because Leia presents the medals, the shorter 1.55 meter Carrie Fisher simply couldn't reach up around the neck of the 2.18 meter tall Peter Mayhew in his Chewbacca costume (see Libbey 2016).

viii At the 50 ${ }^{\text {th }}$ Academy Awards in 1978, A New Hope won Oscars for Visual Effects and for Sound, among many others; while the sound designer also received a Special Achievement Award for his creation of the film's non-human voices, and members of the visual effects team shared the Academy's Scientific and Engineering Award for their development of the Dykstraflex camera and the photographic motion control systems used in the production of the film.

${ }^{\mathrm{ix}}$ Which is compounded in star magazine paratexts such as a photo spread in the June 2015 Vanity Fair by the famous stills photographer Annie Leibovitz, who brought her own star photography body and nonhuman camera-machine to index the legacy cast sitting inside their analogue set for another paratextual media release (see Handy 2015).

${ }^{x}$ Admittedly, however, a CGI of Fisher-as-Leia is briefly employed in a passing scene in a standalone side-line film, 2016's Rogue One: A Star Wars Story — but not in the main series narrative of the franchise. 